\title{
PAVO SPICIFER.
}

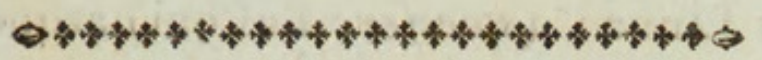

\section{ChARACTER GENERICUS.}

Caput pennis revolutis tectum.

Penna uropygii elongatæ, ocellatæ.

Lin. Syst. Nat. p. $26 \%$.

CHARACTER SPECIFICUS, छ̈C.

PAVO capite cæruleo, pennis cristæ lanceolatis erectis, fascia utrinque suboculari lutea.

PAVO muticus. P. capite crista subulata, calcaribus nullis?

PAVO japonensis.

Lin. Syst. Nat. p. 268.

Aldrov. orn. 2. p. 35.

Eandem sibi patriam vindicat pulcherrima hæc avis quam et pavo vulgaris; Indiani scilicet, ibique præcipue regiones montanas. Moribus modoque vivendi pavoni vulgari similis esse dicitur, a quo etiam verisimile est sæpius non fuisse discretam. Speciem tamen revera esse diversam satis probat B peculiaris 
peculiaris cristæ conformatio, nec non macula saturatim flava utrinque sub oculis sita. Si idem sit pavo muticus Linnæi, (spicifcre Buffoni) atque hæc nostra avis; vel in illo describendo evidenter erratum est, vel variare solent colores et alia nonnulla; Linnæus enim, et Aldrovandus, (qui primus descriptor avem quam depictam adeptus est, repræsentavit,) calcaribus carentem ostendunt; quæ in icone unde deducta est nostra similitudo, admodum conspicua sunt: hanc autem effigiem ipsius avis viventis expressit pictor Indicus, eamque nobiscum perhumaniter communicavit Dominus Fleming, chirurgus Anglicus qui prope Calcuttam in Bengala multos annos versatus est. 



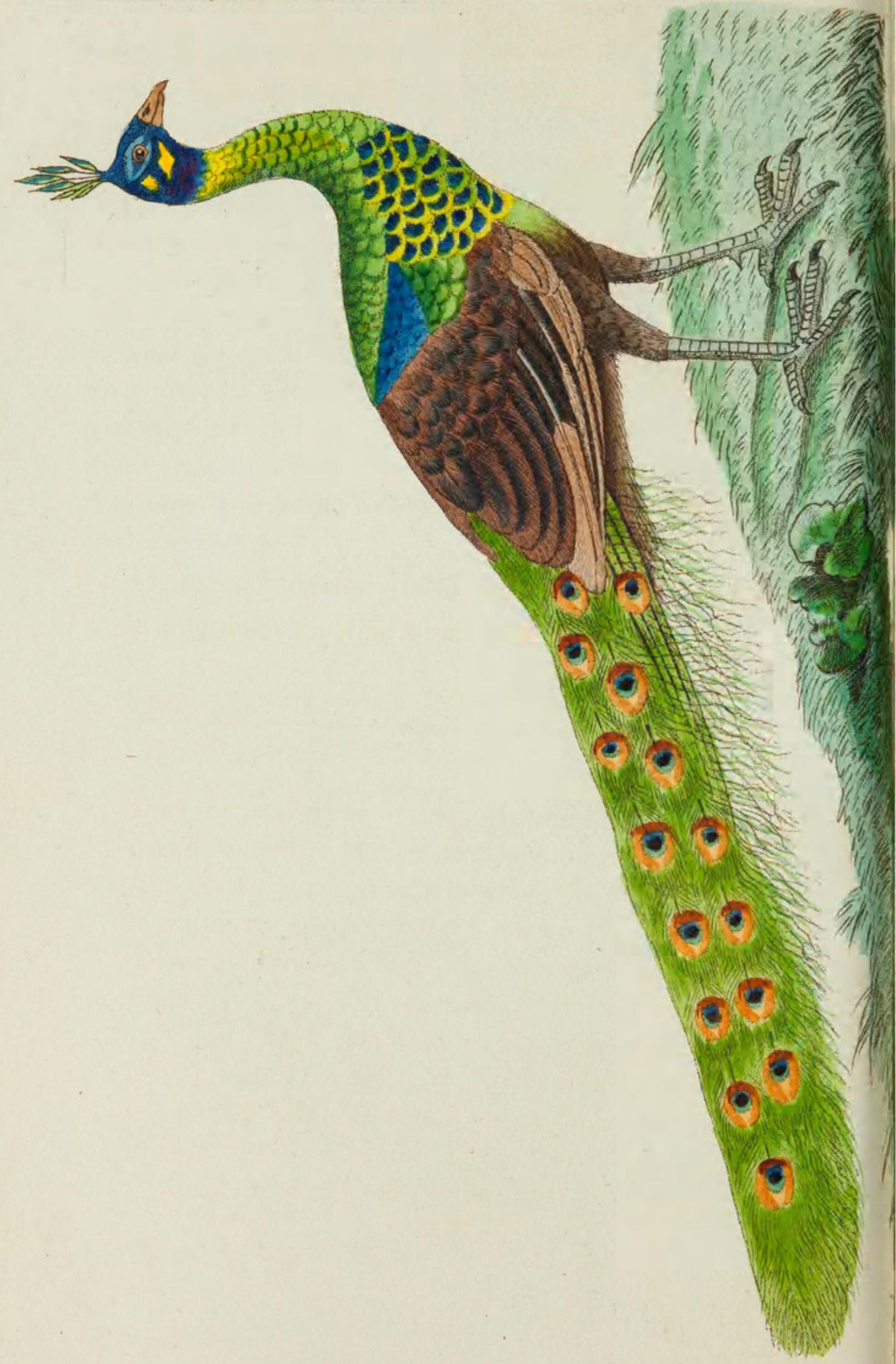


THE

\section{SPIKE-CRESTED PEACOCK.}

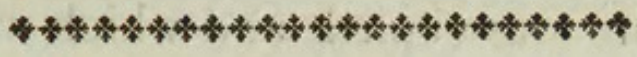 \\ GENERIC CHARACTER.}

Head covered with revolute feathers.

Uropygial feathers elongated and ocellated.

\section{SPECIFIC CHARACTER.}

PEACOCK with blue head, upright lanceolate crest, and yellow band beneath each eye.

The beautiful bird represented on the present plate is, like the common Peacock, a native of India, chiefly inhabiting mountainous regions. It is distinguished as a species by the peculiar structure of its crest, as well as by the bright-yellow patch beneath each eye. In its manners it is said to resemble the common peacock, with which it has probably been often confounded. If it be the bird intended by the Pavo muticus of Linneus, (the Spicifere of Buffon, ) it is evident either that the description of that species is erroneous, or that the bird is subject

B 2 
to vary in colour and other circumstances; since Linnæus and Aldrovandus, (who first described it from a painting, ) represent it as destitute of spurs, which are conspicuous in the drawing from which the present figure was copied, and which was taken from the life in India, and politely communicated by T. Fleming, Esq. several years resident in the neighbourhood of Calcutta in Bengal. 


\section{$2 \mathrm{BHL}$ Biodiversity Heritage Library}

Shaw, George. 1804. "The Spike-Crested Peacock, Pavo spicifer [PI. 641]." The Naturalist's Miscellany 16(CLXXXII), https://doi.org/10.5962/p.311082.

View This Item Online: https://www.biodiversitylibrary.org/item/281942

DOI: https://doi.org/10.5962/p.311082

Permalink: https://www.biodiversitylibrary.org/partpdf/311082

\section{Holding Institution}

Museums Victoria

\section{Sponsored by}

Atlas of Living Australia

\section{Copyright \& Reuse}

Copyright Status: Public domain. The BHL considers that this work is no longer under copyright protection.

This document was created from content at the Biodiversity Heritage Library, the world's largest open access digital library for biodiversity literature and archives. Visit BHL at https://www.biodiversitylibrary.org. 